\title{
Hubungan antara kelekatan orangtua-remaja dengan motivasi belajar pada remaja di SMA Negeri 4 Denpasar
}

\author{
Paul Kevin Manalu dan Adijanti Marheni \\ Program Studi Sarjana Psikologi, Fakultas Kedokteran, Universitas Udayana \\ adijantimarheni@gmail.com
}

\begin{abstract}
Abstrak
Masa remaja merupakan masa dimana manusia sedang berada didalam proses pendidikan. Dalam proses pendidikan anak membutuhkan sebuah dorongan untuk dapat menjalani proses tersebut dengan baik, dorongan tersebut disebut motivasi belajar. Orangtua merupakan salah satu faktor yang dapat membentuk motivasi belajar remaja. Hubungan antara orangtua dan remaja yang terbentuk sejak lama dan memberikan arti khusus pada remaja itu disebut kelekatan. Tujuan dari penelitian ini adalah untuk mengetahui hubungan antara kelekatan orangtua dan remaja dengan motivasi belajar pada remaja di SMA Negeri 4 Denpasar. Teknik pengambilan sampel dalam penelitian ini menggunakan teknik simple cluster sampling. Sampel dalam penelitian ini berjumlah 143 orang, siswa SMA Negeri 4 Denpasar berusia 1516 tahun dan sedang duduk di kelas XI. Peneliti menyebarkan dua skala yaitu skala kelekatan orangtua-remaja yang disusun oleh Dewi (2013), dan skala motivasi belajar yang disusun berdasarkan aspek motivasi intrinsik dan ekstrinsik yang disusun oleh Uno (2011). Data yang telah dikumpulkan dalam penelitian ini kemudian dianalisis dengan menggunakan teknik korelasi product moment untuk melihat hubungan antara variabel kelekatan orangtua dan remaja dengan motivasi belajar. Analisis product moment menghasilkan $r$ hitung 0,356 dengan signifikansi 0,000 $(<0,05)$. Hasil tersebut menunjukkan adanya hubungan yang signifikan dan positif antara kelakatan orangtua-remaja dengan motivasi belajar. Nilai koefisien determinannya adalah 0,127 yang berarti bahwa kelekatan mempunyai kontribusi sebesar $12,7 \%$ terhadap motivasi belajar. Dengan demikian semakin tinggi kelekatan orangtua-remaja maka semakin tinggi juga motivasi belajar remaja.
\end{abstract}

Kata kunci: Motivasi belajar, kelekatan, remaja.

\begin{abstract}
Adolescence becomes a time when humans are in the process of education. In the process of learning child needs an encouragement to help the process, this encouragement is called learning motivation. Parents are one of the factors that can help children learn. This relationship between parent-adolescence that is formed long ago and gives a special meaning to the adolescence is called attachment. The purpose of this research is to know the relationship between parent-adolescence attachment with learning motivation of student in SMA Negeri 4 Denpasar. The sample in this research was taken by applying cluster sampling technique. The population of this study was 143 people, students of Senior High School 4 Denpasar, 15 to 16 years old and were currently in eleventh grade. The researcher disseminate two scales: the adolescent-to-adherence paradigms compiled by Dewi (2013), and the learning motivation scale based on the intrinsic and extrinsic aspects of motivation compiled by Uno (2011). The collected data in this research then analyzed by using product moment correlation technique to see the correlation between parent-child attachment variable with learning motivation. Analysis of product moment resulted $r$ observed 0.356 at the level of significance $0.000(<0.05)$. Coefficient of determination equal to 0,127 indicates the attachment contribution to the learning motivation is $12,7 \%$, These result indicated a significant and positive relationship between parent-adolescence attachment with learning motivation. Thus the higher the parent- adolescence attachment the higher the adolescence's learning motivation.
\end{abstract}

Keywords: Learning motivation, attachment, adolescence. 


\section{LATAR BELAKANG}

Masa remaja merupakan periode transisi atau peralihan dari masa anak menuju masa dewasa. Pada masa ini individu mengalami berbagai perubahan, baik fisik maupun psikis (Agustiani, 2006). Selain itu remaja juga sudah berubah secara kognitif dan mulai mampu berpikir abstrak seperti orang dewasa. Perubahan Kognitif memainkan peranan penting dalam membantu remaja menanggulangi tuntutan pendidikan dan kejuruan yang semakin kompleks (Conger, 1989). Masa remaja merupakan masa dimana manusia berada didalam proses pendidikan. Ketika seorang remaja memasuki dunia pendidikan, maka remaja akan dituntut untuk mampu mencapai hasil yang memuaskan dalam hal kecakapan maupun kecerdasannya. Proses belajar mengajar hendaknya juga dilakukan secara sadar dan terorganisir dengan baik untuk mencapai apa yang diharapkan. Pembelajaran bukanlah suatu proses yang sederhana, karena pembelajaran sangat berkaitan dengan pengembangan potensi manusia. Pada masa kini, tuntutan yang harus dipenuhi remaja dalam proses belajar mengajar semakin banyak. Batas bawah nilai ujian nasional yang selalu meningkat dan persaingan untuk mendapatkan posisi di kursi universitas mendorong remaja untuk bisa membangun proses kegiatan belajar yang baik untuk bisa mencapai beberapa target yang harus dipenuhi dalam proses belajar.

Sebelumnya peneliti telah melakukan wawancara kepada lima orang siswa SMA di Denpasar secara terpisah untuk mengetahui bagaimana mereka menghadapi masa sekolah dan mengatasi masalah yang mungkin ditemukan. Dari lima siswa, dua di antaranya termasuk siswa yang berprestasi di sekolah. Mereka mendapatkan ranking lima besar di sekolahnya. Sementara yang tiga orang siswa lainnya mengaku hanya siswa biasa yang tidak memiliki prestasi akademik. Dari wawancara yang dilakukan diketahui bahwa ada perbedaan yang cukup terlihat diantara kelima siswa tersebut. Kedua siswa berprestasi sama-sama memiliki waktu belajar khusus untuk mengulang kembali pelajaran yang sudah diterima disekolah. Mereka juga mempunyai target yang ingin mereka capai di setiap semester. Bahkan salah satu dari siswa berprestasi tersebut telah menentukan reward yang akan diberikan orangtuanya jika target yang sudah ditentukan dalam satu semester tersebut bisa tercapai dengan baik. Sementara tiga siswa yang tidak berprestasi mengatakan bahwa mereka tidak membuat waktu khusus untuk belajar dirumah karena mereka mengatakan bahwa belajar di sekolah sudah cukup sehingga mereka bisa melakukan kegiatan lain yang menurut mereka lebih menarik seperti bermusik dan berolahraga.

Dari wawancara yang dilakukan penulis dapat diketahui bahwa setiap siswa mempunyai cara nya masing-masing untuk menghadapi proses belajar di sekolah. Sementara tuntutan yang diberikan pihak sekolah kepada semua siswa adalah sama, yaitu mampu mengikuti pelajaran di sekolah dengan baik. Oleh sebab itu dibutuhkan sesuatu yang dapat mendorong siswa untuk dapat menjalani proses pembelajaran tersebut. Dorongan tersebut dikenal dengan nama motivasi belajar.
Motivasi belajar terdiri dari dua kata, motivasi dan belajar. Kata motivasi pada dasarnya berasal dari bahasa latin yaitu movere yang berarti menggerakkan. Sedangkan dalam bahasa Indonesia kata motivasi berawal dari kata motif, yang memiliki arti kekuatan yang terdapat pada diri seorang individu yang menyebabkan seorang individu bisa bertindak atau berbuat sesuatu (Papalia,2010). Walgito (2010) mengatakan bahwa motivasi biasanya terbentuk sebagai sebuah siklus untuk memenuhi kebutuhan, artinya ketika individu mempunyai sebuah kebutuhan yang harus dipenuhi, maka motivasi akan muncul dan motivasi ini memunculkan prilaku atau tindakan yang dapat membuat kebutuhan tersebut bisa terpenuhi. Ketika kebutuhan sudah terpenuhi, maka motivasi tersebut pun hilang. Siklus ini akan selalu terbentuk ketika ada kebutuhan lainnya yang harus dipenuhi. Dalam kamus besar bahasa indonesia, belajar diartikan sebagai usaha untuk memperoleh kepandaian atau ilmu. Dengan kata lain, belajar adalah suatu proses yang dijalani individu untuk mendapatkan ilmu pegetahuan. Belajar merupakan suatu aktivitas psikis yang berlangsung dalam interaksi dengan lingkungan yang menghasilkan perubahan dalam pengetahuan, pemahaman, keterampilan, nilai dan sikap di mana perubahan ini berlangsung relatif konstan (Winkel, 1996).

Motivasi belajar adalah sebuah daya penggerak didalam diri seorang siswa yang menimbulkan kegiatan belajar, menjamin kelangsungan kegiatan belajar dan memberikan arah pada kegiatan belajar itu demi mencapai suatu tujuan (Winkel, 1996). Motivasi belajar juga memegang peranan penting dalam memberikan gairah atau semangat dalam belajar, sehingga siswa yang bermotivasi kuat memiliki energi yang banyak untuk melakukan kegiatan belajar. Sardiman (2011) mengatakan bahwa motivasi belajar terbentuk secara berbedabeda antar individu. Motivasi belajar akan menumbuhkan gairah didalam diri siswa dan memberikan semangat untuk menjalankan proses belajar. Siswa yang memilik motivasi tinggi tentunya memiliki semangat yang lebih tinggi dibandingkan siswa dengan motivasi rendah. Dan siswa yang memiliki motivasi yang tinggi juga akan mempunyai banyak energi yang dapat digunakan untuk menyelesaikan kegiatan belajarnya. Dapat disimpulkan bahwa motivasi inilah yang mendorong siswa untuk dapat tekun belajar selama proses pendidikan berlangsung sampai selesainya nanti. Hal ini diperkuat dengan penelitian yang telah dilakukan oleh Rafiqah (2013) yang menyatakan bahwa adanya pengaruh motivasi belajar terhadap prestasi belajar pada siswa kelas XI di SMA Negeri 2 Metro tahun ajaran 2012-2013.

Dalam prosesnya, setiap siswa diharapkan memiliki motivasi belajar yang tinggi, namun pada kenyataannya para siswa masih banyak yang malas untuk belajar, tidak aktif dalam menyelesaikan tugas-tugas yang diberikan tenaga pengajar, dan tidak memiliki dorongan yang kuat untuk mencari tahu hal-hal baru seputar ilmu pengetahuan. Sehingga hal ini mengakibatkan beberapa siswa mendapatkan hasil belajar yang kurang maksimal. Crow dan Crow (dalam Rusyan, 1992) menyatakan bahwa, kegiatan belajar akan tercipta apabila minat atau motif belajar yang ada dalam diri peserta didik itu akan memperkuat motif ke arah tingkah laku tertentu atau dalam hal ini belajar. Minat ini bisa muncul didalam diri para siswa, jika siswa mempunyai ketertarikan khusus akan 
sesuatu yang diharapkan bisa memenuhi kebutuhannya dan hal yang akan dipelajarinya tersebut bisa memberi makna atau arti bagi kehidupannya. Tinggi rendahnya motivasi belajar siswa di sekolah sebenarnya dipengaruhi oleh beberapa hal. Santosa dan Tawardjono (2016) dalam penelitiannya menemukan bahwa ada dua faktor yang mempengaruhi motivasi belajar siswa kelas XI jurusan teknik sepeda motor SMK Muhammadiyah 1 Bambanglipuro yaitu faktor ekstrinsik dan faktor intrinsik. Faktor ekstrinsik terdiri dari unsur dinamis dalam proses belajar, upaya guru dalam memberikan pembelajaran dan kondisi lingkungan belajar dari siswa tersebut. Sedangkan faktor intrinsik nya terdiri dari kondisi siswa , kemampuan siswa dan cita-cita siswa tersebut. Hal ini diperjelas oleh Uno (2011) dengan membagi aspek-aspek motivasi belajar menjadi dua bagian, yaitu motivasi intrinsik dan motivasi ekstrinsik. Motivasi intrinsik dalam motivasi belajar yaitu berupa hasrat dan keinginan berhasil, adanya dorongan kebutuhan belajar, dan harapan akan cita-cita. Motivasi ekstrinsik dalam motivasi belajar yaitu adanya penghargaan, lingkungan belajar yang kondusif, dan kegiatan belajar yang menarik.

Dalam wawancara yang dilakukan penulis kepada lima siswa SMA di Denpasar, dapat diketahui bahwa motivasi belajar kelima siswa tersebut dipengaruhi oleh beberapa faktor seperti cita-cita yang ingin dicapai, gengsi, teman sebaya, lingkungan belajar dan yang paling berpengaruh adalah dukungan keluarga yang dalam hal ini adalah orang tua. Hal ini diperkuat dengan adanya penelitian yang dilakukan Nurhidayah (2012) yang menyatakan adanya pengaruh yang signifikan dari dukungan orang tua terhadap motivasi belajar pada mahasiswa PGSD FKIP Universitas Ahmad Dahlan.

Tidak dapat diingkari bahwa keluarga merupakan lingkungan primer hampir setiap individu dari lahir sampai akhir hidupnya, termasuk ketika individu berada dalam masa remaja. Hubungan orangtua-remaja diungkapkan oleh Santrock (2011) dalam bentuk model lama dan model baru. Model lama menunjukkan ketika beranjak dewasa, remaja memisahkan diri dari orangtua menunjukkan bahwa konflik yang terjadi antara orangtua-remaja sangat kuat dan penuh tekanan. Berbeda dengan model lama, model baru menekankan bahwa orangtua menjadi figur lekat yang penting dan sebagai sistem pendukung saat remaja mengeksplorasi dunia sosial yang lebih luas dan kompleks. Dukungan dari orangtua dapat dirasakan bila remaja memiliki hubungan emosional yang kuat dengan orangtua.

Hubungan antara orang tua dan anak yang terjadi begitu lama ini pun membentuk sebuah hubungan emosional. Menurut Ainsworth (dalam Papalia, 2010) hubungan emosional dalam jangka waktu yang relatif lama disebut dengan kelekatan. Kelekatan merupakan ikatan emosional abadi dan resiprokal antara bayi dan pengasuhnya, yang saling memberikan kontribusi terhadap kualitas hubungan pengasuh dan bayi (Papalia, 2010). Pendapat lain mengatakan bahwa kelekatan merupakan suatu ikatan emosional yang kuat yang dikembangkan anak melalui interaksinya dengan orang yang mempunyai arti khusus dalam kehidupannya, biasanya orang tua (Ainsworth dalam Eliasa, 2011). Bowlby (dalam Monks,
2002) mengatakan bahwa timbulnya kelekatan terhadap figur lekat (biasanya ibu) adalah suatu akibat menjadi aktifnya suatu sistem tingkah laku yang membutuhkan kelekatan dengan ibu. Papousek (dalam Monks, 2002) menyatakan bahwa perhatian yang diberikan orang dewasa sangat dibutuhkan anak dalam perkembangan kognisi dan emosional anak. Berdasarkan kualitas hubungan antara anak dan pengasuh, anak akan mengembangkan konstruksi mental yang biasanya disebut dengan internal working model yang digunakan anak untuk mengidentifikasi diri sendiri dan orang lain yang akan menjadi prototip dalam hubungan sosialnya (Bowlby dalam Ervika, 2005). Model inilah yang kemudian menggiring anak daalm berinteraksi dengan lingkungannya dimasa yang akan datang. Interaksi interpersonal dihasilkan dan diinterpretasikan berdasarkan gambaran mental yang dimiliki seorang anak (Ervika, 2005). Allen (dalam Santrock, 2002) mengatakan bahwa kelekatan antara orangtua-anak akan membantu kompetensi sosial dan kesejahteraan sosial anak pada masa remaja. Hal ini tercermin dari penyesuaian emosional, kesehatan fisik dan harga diri pada anak di masa remaja. Jadi ketika kelekatan yang terbentuk antara orangtua-anak adalah kelekatan yang aman maka anak akan memiliki harga diri, dan kesejahteraan emosional yang lebih baik pula. Dan kelekatan tersebut juga mempunyai peran dalam kemampuan berinteraksi anak dengan teman sebaya dan membangun relasi yang baik dengan orang lain di luar anggota keluarga.

Kelekatan memberi sumbangan terhadap perkembangan manusia sepanjang hidupnya melalui dukungan emosional dan rasa kedekatan, dalam hal ini adalah dari orangtua terhadap remaja. Jadi ketika remaja belajar untuk menjalin hubungan dengan orang diluar keluarganya (seperti lingkungan dan sekolah), dukungan dari keluarga akan memampukan remaja untuk lebih percaya diri dan terbuka terhadap orang lain (Rice \& Dolgin, 2001). Inilah yang mendasari peneliti untuk mengangkat judul penelitian mengenai "Hubungan Antara Kelekatan Orangtua-Remaja dengan Motivasi Belajar pada Remaja di SMA Negeri 4 Denpasar".

\section{METODE PENELITIAN}

\section{Variabel dan Definisi Operasional}

Variabel bebas dalam penelitian ini adalah kelekatan antara orangtua dan remaja. Variabel terikat dalam penelitian ini adalah motivasi belajar. Definisi operasional kedua variabel dalam penelitian ini adalah sebagai berikut:

Kelekatan antara Orangtua dan Remaja

Kelekatan antara orangtua dan remaja merupakan ikatan emosional yang terbentuk dalam waktu yang relatif lama antara orangtua dan remaja, dan memberikan arti khusus pada remaja. Skala kelekatan orangtua-remaja yang digunakan dalam penelitian ini diadaptasi dari skala kelekatan orangtuaremaja yang dikembangkan oleh Dewi (2013). Dewi mengembangkan skala kelekatan orangtua-remaja dengan menggunakan aspek-aspek kelekatan yang dikemukakan oleh Bowlby, yaitu kepercayaan, komunikasi, dan keterasingan.

\section{Motivasi Belajar}


Motivasi belajar merupakan dorongan psikis yang terbentuk dari dalam diri dan luar diri siswa yang dapat menjamin keberlangsungan belajar untuk mencapai tujuannya dalam proses belajar. Skala motivasi belajar yang digunakan dalam penelitian ini disusun oleh peneliti dengan menggunakan aspek motivasi intrinsik dan ekstrinsik yang disusun oleh Uno (2004).

\section{Responden}

Populasi dalam penelitian ini adalah siswa SMA Negeri 4 Denpasar. Karakteristik sampel dalam penelitian ini adalah siswa SMA Negeri 4 Denpasar yang duduk di kelas XI, berusia 15-16 tahun, dan tinggal bersama orangtua. Peneliti memilih siswa kelas XI karena pihak sekolah hanya memberikan izin untuk menggunakan siswa kelas XI karena siswa kelas X sedang sibuk ulangan beberapa kegiatan sekolah dan siswa kelas XII sedang ujian nasional. Dalam penelitian ini, peneliti menggunakan metode random sampling dengan teknik cluster sampling. Cara pengambilan sampel dilakukan dengan cara membagi kelas XI menjadi dua yaitu kelas IPA dan IPS. Setelah kelas IPA terpilih, dari beberapa kelas IPA diilih empat kelas yang akan digunakan untuk mengambil data. Jumlah responden dalam penelitian ini adalah 150 siswa.

\section{Tempat Penelitian}

Tempat pengambilan sampel dalam penelitian ini adalah SMA Negeri 4 Denpasar. Peneltian ini dilaksanakan pada bulan April 2018.

\section{Alat Ukur}

Metode pengumpulan data yang digunakan dalam penelitian ini adalah dengan menggunakan dua skala yaitu skala kelekatan orangtua-remaja dan skala motivasi belajar. Skala kelekatan orangtua-remaja yang digunakan dalam penelitian ini diadaptasi dari skala kelekatan orangtua-remaja yang dikembangkan oleh Dewi (2013). Dewi mengembangkan skala kelekatan orangtua-remaja dengan menggunakan aspekaspek kelekatan yang dikemukakan oleh Bowlby, yaitu kepercayaan, komunikasi, dan keterasingan. Skala motivasi belajar dalam penelitian ini disusun peneliti dengan berdasarkan teori yang dikemukakan oleh Uno (2011). Skala kelekatan orangtua-remaja terdiri dari 25 aitem dan skala motivasi belajar terdiri dari 46 aitem. Dalam penelitian ini peneliti menggunakan teknik skala likert dan aitem yang ada di kedua skala terbagi menjadi pernyataan yang favorable dan unfavorable. Pada pernyataan yang favorable setiap jawaban Sangat Tidak Setuju (STS) akan diberi nilai 1, Tidak Setuju (TS) akan diberi nilai 2, Kurang Setuju (KS) akan diberi nilai 3, Setuju (S) akan diberi nilai 4,dan Sangat Setuju (SS) akan diberi nilai 5. Sebaliknya, pada pernyataan unfavorable setiap jawaban Sangat Tidak Setuju (STS) akan diberi nilai 5, Tidak Setuju (TS) akan diberi nilai 4, Kurang Setuju (KS) akan diberi nilai 3, Setuju (S) akan diberi nilai 2,dan Sangat Setuju (SS) akan diberi nilai 1.

Hasil uji validitas yang dilakukan terhadap skala motivasi belajar diperoleh aitem yang valid memiliki nilai koefisien validitas yang berkisar antara 0,303-0,623. Hasil uji reliabilitas pada skala motivasi belajar dengan menggunakan Cronbach Alpha adalah sebesar 0,884 yang menunjukkan bahwa skala motivasi belajar ini mampu menggambarkan $88,4 \%$ variasi pada skor subjek adalah skor murni. Dengan kata lain, skala motivasi belajar ini mampu mengukur motivasi belajar pada siswa. Uji validitas pada skala kelekatan menunjukkan bahwa aitem yang dinyatakan valid memiliki koefisien validitas yang berkisar antara 0,386-0,753. Hasil uji reliabilitas pada skala Kelekatan dengan menggunakan Cronbach Alpha adalah sebesar 0,923 yang menunjukkan bahwa skala kelekatan ini mampu menggambarkan 92,3\% variasi pada skor subjek adalah skor murni. Dengan kata lain, skala kelekatan ini mampu mengukur kelekatan.

\section{Metode Pengumpulan Data}

Peneliti menggunakan skala atau kuesioner dalam mengumpulkan data dari subjek penelitian. Skala yang digunakan ada dua, yaitu skala kelekatan orangtua-remaja dan skala motivasi belajar. Peneliti menyebarkan 150 kuesioner kepada kelas yang sebelumnya sudah ditentukan secara acak. Setelah kuesioner dikumpulkan, ada tujuh buah kuesioner yang tidak dapat dianalisis karena tidak diisi dengan sempurna.

\section{Teknik Analisis Data}

Penelitian ini menggunakan metode analisis data dengan analisis korelasi pearson product moment dengan menggunakan program SPSS 16.0 for windows. Metode analisis ini dipilih karena penelitian ini ingin mengentahui hubungan antara 2 variabel. Pada analisis ini mensyaratkan bahwa populasi asal sampel mempunyai dua varian dan berdistribusi normal. Uji normalitas pada penelitian ini menggunakan Kolmogorof Smirnov yang ada pada program SPSS 16.0 for windows. uji linearlitas diuji dengan melihat compare mean lalu menggunakan test of linearity, dapat dilakukan dengan bantuan software SPSS 16.0 for windows.

\section{HASIL PENELITIAN}

\section{Uji Asumsi}

Dari data tabel 1 (terlampir) dapat diketahui bahwa variabel kelekatan memiliki distribusi yang normal, karena memiliki nilai sebesar 1.273 dengan signifikansi $0,78(\mathrm{p}>0,05)$. Variabel motivasi belajar juga memiliki distribusi yang normal karena memiliki nilai sebesar 0,608 dengan signifikansi nya 0,853 $(\mathrm{p}>0,05)$. Dari hasil uji linieritas pada variabel dalam penelitian ini diperoleh nilai signifikansi linierity pada kedua variabel adalah 0,000 . Nilai tersebut lebih kecil dari 0,05 yang berarti adanya hubungan yang linier antara variabel kelekatan dan motivasi belajar. Setelah diperoleh bahwa kedua variabel dalam penelitian ini berdistribusi normal dan memiliki sifat linear, maka peneliti dapat melanjutkan penelitian ini dengan menguji hipotesis menggunakan korelasi product moment.

\section{Uji Hipotesis}

Dalam penelitian ini peneiliti menggunakan teknik korelasi product moment untuk menguji hipotesis yang telah diajukan. Dari hasil uji hipotesis diatas diketahui bahwa nilai koefisien korelasi antara kelekatan orangtua-anak dengan motivasi belajar sebesar 0.356 dengan $\mathrm{p}=0,000$. Berdasarkan data diatas dapat dilihat bahwa koefisien korelasi adalah 0.356 dengan signifikansi 0,000 . Karena nilai signifikansinya lebih kecil dari 
0,05 maka Ho ditolak dan Ha diterima. Itu berarti bahwa ada hubungan yang signifikan antara kelekatan orangtua-anak dengan motivasi belajar siswa di SMA Negeri 4 Denpasar. Nilai koefisien determinan dalam penelitian ini dapat dilihat di tabel 4 (terlampir), diperoleh bahwa nilai koefisien determinan dalam penelitian ini adalah 0,127. Berdasarkan nilai koefisien determinan tersebut, dapat diinterpretasikan bahwa variabel bebas (kelekatan orangtua-remaja) memiliki kontribusi sebesar $12,7 \%$ terhadap variabel terikat (motivasi belajar) dan $87,3 \%$ lainnya dipengaruhi oleh faktor lain.

\section{Analisis Data Tambahan}

Peneliti menemukan beberapa informasi tambahan yang didapatkan melalui analisis dalam penelitian ini. Dari tabel 5 (terlampir) dapat diketahui bahwa subjek termasuk dalam kategori rendah sebanyak $1,39 \%$, kategori sedang sebanyak $45,46 \%$ dan kategori tinggi sebanyak 53,15\%. Berdasarkan tabel diatas ada 2 orang termasuk dalam kategori rendah, 65 orang dalam kategori sedang dan 76 orang dalam kategori tinggi. Dari tabel 6 (terlampir) dapat diketahui bahwa subjek termasuk dalam kategori rendah sebanyak 2,09\%, kategori sedang sebanyak 79,03\% dan kategori tinggi sebanyak $18,89 \%$. Berdasarkan tabel diatas ada 3 siswa yang termasuk dalam kategori motivasi belajar rendah, 113 orang berada dalam kategori sedang dan 27 orang berada dalam posisi tinggi.

\section{PEMBAHASAN DAN KESIMPULAN}

Hasil analisis dari data yang telah berhasil dikumpulkan dalam penelitian ini menunjukkan bahwa adanya hubungan yang signifikan antara kelekatan orangtua-remaja dengan motivasi belajar remaja disekolah. Dan dapat dikatakan bahwa semakin tinggi kelekatan anak dengan orang tua maka motivasi belajar nya pun akan meningkat. Dari hasil analisis dapat disimpulkan kelekatan yang terjadi antara siswa SMA Negeri 4 Denpasar dengan orang tua nya sebagian besar berada pada kategori yang tinggi. Sebanyak 76 siswa berada dalam posisi ini, dan ada 65 siswa berada dalam posisi kelekatan yang sedang dan 2 siswa berada pada tingkat kelekatan yang rendah. Pada tahap ini anak dianggap mampu untuk membangun komunikasi yang baik dengan orang tua dan mempunyai rasa percaya dengan orang tua nya. Orang tua dianggap mampu untuk memberikan rasa aman kepada anak.Hal ini mulai terbentuk sejak kecil bahkan sejak anak mendapatkan sentuhan fisik pada masa awal kehidupannya.

Hasil analisis juga menunjukkan bahwa sebagian besar siswa SMA Negeri 4 Denpasar memiliki motivasi belajar dalam kategori yang sedang. Sebanyak 113 siswa memiliki motivasi belajar dalam kategori yang sedang, 27 orang siswa yang memiliki motivasi belajar tinggi dan 3orang lainnya berada dalam kategori motivasi belajar yang rendah. Dapat dikatakan bahwa sebagian besar siswa SMA Negeri 4 Denpasar sudah memiliki dorongan-dorongan yang diperlukan untuk membentuk motivasi belajar mereka disekolah. Motivasi belajar ini yang akan menjadi penggerak dalam diri siswa untuk mencapai tujuan yang diinginkan.

Dalam penelitian yang dilakukan oleh Dewi (2013) diketahui bahwa kelekatan antara orangtua-anak berperan dalam membentuk kemandirian seorang anak. Kemandirian tersebut digambarkan sebagai kemampuan anak dalam melakukan tugas dan tanggung jawab yang harus dilakukannya. Anak yang memasuki usia remaja diharapkan mampu untuk melepaskan ketergantungannya dengan orang tua untuk mengerjakan tugas dan tanggung jawabnya. Hal ini termasuk dalam membangun motivasi belajar nya disekolah. Dengan motivasi belajar yang terbentuk, anak diharapkan mampu untuk mencapai tujuannya dengan baik.

Aryanti (2015) menyatakan bahwa proses kelekatan itu adalah fase awal perkembangan psikoemosional, psikososial dan kognitif anak. Hal ini akan mempunyai peran yang membentuk keberanian anak untuk mengeksplorasi lingkungannya. Kelekatan yang aman akan membentuk keberanian anak untuk mengeksplorasi figure lekat nya, bahkan ketika figure lekatnya tersebut tidak terihat. Dan ketika anak tergolong dalam kelekatan yang tidak aman maka anak akan menjadi tidak percaya diri pada lingkungan sekitar, anak cenderung minder bahkan anak kurang mempunyai minat dalam belajar.

Dukungan orang tua merupakan salah satu hal yang mendukung terbentuknya motivasi belajar siswa. Hal ini diperjelas oleh penelitian yang dilakukan oleh Nurhidayah (2012) yang mengemukakan bahwa dua hal yang mendukung terbentukya motivasi belajar siswa adalah minat belajar dan dukungan dari orang tua. Dukungan dari orang tua dapat berupa fasilitas yang disediakan orang tua, perhatian yang diberikan kepada anak dan reward dan punishment. Hasil penelitian Nurhidayah menunjukkan bahwa semakin tinggi dukungan yang diberikan orang tua maka semakin tinggi juga motivasi belajar anak.

Dari tabel kategorisasi variabel motivasi belajar dapat disimpulkan bahwa sebagia besar siswa SMA Negeri 4 Denpasar telah mampu membangun motivasi belajarnya. Sebanyak 113 siswa berada di kategori sedang dan 27 siswa berada di kategori yang tinggi. Hanya 3 siswa yang memiliki motivasi belajar dengan kategori rendah. Hal ini menunjukkan bahwa siswa telah mampu membangun dorongan-dorangan dari dalam diri mereka yang dapat berguna untuk membentuk motivasi belajar nya disekolah dan diharapkan mampu mencapai tujuan nya dalam belajar.

Dari tabel kategorisasi variabel kelekatan orangtua-anak dapat disimpulkan bahwa sebagian besar siswa SMA Negeri 4 Denpasar berada dalam kelekatan yang tinggi dengan orangtuanya. Sebanyak 76 siswa memiliki kelekatan yang tinggi, dan 65 siswa lainnya berada dikategori kelekatan yang sedang. Sedangkan 2 siswa mempunyai kelekatan pada kategori yang rendah. Hal ini menunjukkan bahwa orang tua telah mampu membangun hubungan kelekatan yang baik dengan sebagian besar siswa di SMA Negeri 4 Denpasar. Sehingga anak mampu membangun kepercayaan dan komunikasi yang baik dengan orang tua.

Dari hasil uji hipotesis yang telah dilakukan, dapat diketahui bahwa adanya hubungan yang signifikan antara kelekatan orangtua-remaja dengan motivasi belajar remaja disekolah. Hal itu ditunjukkan dari nilai koefisien korelasi antara kelekatan orangtua-remaja dengan motivasi belajar sebesar 0,356 dengan nilai signifikansi $\mathrm{p}=0,000$. Dan berdasarkan 
kategori korelasi yang dibentuk Karl Pearson, maka nilai korelasi dalam penelitian ini tergolong dalam kategori korelasi yang lemah. Nilai koefisien determinan sebesar 0,127 menunjukkan bahwa kelekatan orangtua-remaja memiliki kontribusi sebesar $12,7 \%$ terhadap motivasi belajar remaja disekolah. Hal ini dikarenakan adanya faktor-faktor lain yang mempengaruhi motivasi belajar.

Seperti yang dijelaskan sebelumnya bahwa ada beberapa faktor lain yang mempengaruhi terbentuknya motivasi belajar siswa yaitu, kultur, tempat menuntut ilmu dan diri sendiri. Dalam penelitian yang dilakukan Rahmawati (2016) ditemukan bahwa ada tiga faktor penting yang mempengaruhi motivasi belajar siswa. Faktor tersebut antara lain:

Tempat Menuntut Ilmu.

Peran guru, materi pengajaran dan teman sekolah termasuk dalam faktor tempat menuntut ilmu atau lingkungan sekolah. Peran guru memiliki pengaruh paling besar dalam pembentukan motivasi belajar siswa. Sebanyak 86 siswa mengatakan bahwa upaya guru dalam memberikan pengajaran merupakan faktor yang mempengaruhi motivasi belajarnya. Sedangkan sebanyak 74 siswa mengatakam bahwa ketertarikkan terhadap materi memperngaruhi motivasi belajar mereka. Dan sebanyak 59 siswa mengatakan lingkungan teman sebaya juga mempengaruhi motivasi belajar mereka.

$\underline{\text { Kultur }}$

Sebayak 52 siswa mengatakan bahwa motivasi belajar mereka dipengaruhi oleh cita-citanya. Cita - cita terbentuk dari pemahaman dan nilai-nilai tersendiri siswa dalam proses belajar. Dan hal ini juga dipengaruhi oleh sistem nilai yang dianut orangtua.

Diri Sendiri

Dan yang terakhir adalah diri sendiri. Sebanyak 21 siswa mengatakan bahwa faktor kondisi rohani dan konsentrasi mereka dalam belajar mempunyai pengaruh yang besar dalam pembentukan motivasi belajarnya di sekolah. Kondisi jasmani dan rohani yang stabil akan meningkatkan tingkat konsentrasi belajar siswa. Dan sebaliknya, jika kondisi jasmani dan rohani tidak stabil, maka konsentrasi belajar siswa juga akan terganggu.

Penelitian ini memiliki beberapa kendala, yang pertama adalah dalam proses pengambilan data, peneliti tidak bisa mendampingi seluruh subjek ketika mengisi skala, sehingga ada skala yang tidak diisi dengan sempurna. Kendala kedua adalah proses perijinan pengambilan data dari sekolah cukup lama, dan waktu yang diberikan hanya satu hari. Kendala ketiga adalah peneliti hanya bisa mengambil data dari kelas XI, karena kelas X sedang sibuk ulangan dan ada kegiatan disekolah dan kelas XII sedang dalam proses persiapan ujian nasional.

Dari pemaparan analisis data yang telah didapatkan maka tujuan penelitian ini sudah terpenuhi yaitu untuk mengetahui hubungan antara kelekatan orangtua-anak dengan motivasi belajar anak. Kelekatan orangtua-anak yang tinggi akan meningkatkan motivasi belajar anak. Dan ketika kelekatan orangtua-anak rendah, maka motivasi belajar anak pun akan menurun pula.

Berdasarkan hasil analisis data yang sudah dijelaskan maka kesimpulan dari penelitian ini adalah terdapat hubungan yang signifikan antara kelekatan orangtua-remaja dengan motivasi belajar pada remaja di SMA Negeri 4 Denpasar. Siswa SMA Negeri 4 Denpasar memiliki motivasi belajar dalam kategori sedang. Ada 27 siswa yang mempunyai motivasi belajar dalam kategori tinggi dan hanya 3 siswa yang memiliki motivasi belajar dalam kategori rendah. Siswa SMA Negeri 4 Denpasar memiliki kelekatan dalam kategori tinggi dengan orang tua mereka. Sebanyak 65 siswa memiliki kelekatan dalam kategori sedang dan sebanyak 2 siswa yang memiliki kelekatan dalam kategori rendah dengan orangtuanya.

Dari proses penelitian ini, peneliti dapat memberikan beberapa saran. Orangtua diharapkan mampu membangun hubungan yang baik dengan anak karena hubungan antara orangtua dengan anak memilik pengaruh yang besar dalam keberlangsungan hidup anak. Anak diharapkan mampu untuk membangun dorongan-dorangan yang diperlukan untuk membentuk motivasi belajar nya disekolah, sehingga anak mampu mencapai semua tujuan yang diharapkan dan mampu menggapai cita-cita yang diinginkan. Para guru diharapkan mampu menerapkan gaya mendidik yang membuat anak didik merasa nyaman dalam menjalani proses belajar disekolah. Saran untuk peneliti selanjutnya adalah peneliti selanjutnya diharapkan mampu mengembangkan pengaruh kelekatan terhadap keadaan anak disekolah. Misalnya menggali lebih dalam dampak dari jenis kelekatan terhadap motivasi belajar anak disekolah. Mengembangkan alat ukur dengan bahasa yang lebih gampang dicerna subjek penelitian untuk meminimalisir kesalahan dalam pengambilan data.

\section{DAFTAR PUSTAKA}

Agustiani,Hendrianti (2006). Psikologi Perkembangan : Pendekatan Ekologi Kaitanya dengan Konsep Diri dengan Penyesuaian Diri Pada Remaja.Bandung. Refika Aditama

Aryanti, Zusy (2015). Kelekatan Dalam Perkembangan Anak. Metro. Jurnal Tarbawiyah Vol 12 nomor 2, 245-258

Conger, J.J. (1989). Perkembangan dan Kepribadian Anak. Jakarta. Arcan

Dewi, Audy Ayu Arisha(2013). Hubungan Kelekatan OrangtuaRemaja dengan Kemandirian Pada Remaja di SMKN 1 Denpasar. Skripsi. Denpasar. Program Studi Psikologi Fakultas Kedokteran Universitas Udayana.

Eliasa, E. I. (2011). Pentingnya kelekatan orangtua dalam internal working model untuk pembentukan karakter anak (kajian berdasarkan teori kelekatan dari john bowlby). Yogyakarta: Inti Media Yogyakarta.

Ervika, Eka (2005). Kelekatan (attachment) Pada Anak. Makalah Ilmiah. Sumatera Utara. Program Studi Psikologi Fakultas Kedokteran Universitas Sumatera Utara. Dipublikasikan.

Monks,F.J, Knoer. A.M.P \& Haditono, S.R. (2002). Psikologi Perkembangan : Pengantar dalam Berbagai Bagiannya. Yogyakarta: Gadjah Mada University Pers

Nurhidayah (2012). Faktor-Faktor Yang Mempengaruhi Motivasi Belajar Mahasiswa Program Studi PGSD Universitas Ahmad Dahlan. Jurnal Universitas Ahmad Dahlan. Dipublikasikan.

Papalia, D.E., Old, S. W., \& Feldman, R. D. (2010). Human development (psikologi perkembangan) edisi kesembilan. Jakarta: Kencana. 
Rafiqah, Mar'atur (2013). Pengaruh Motivasi Belajar Terhadap Prestasi Belajar. Skripsi. Lampung. Program Studi Bimbingan Konseling FKIP Universitas Lampung. Dipublikasikan.

Rahmawati, Rima (2016). Faktor-Faktor Yang Mempengaruhi Motivasi Belajar Siswa Kelas X SMA Negeri Piyungan Pada Pelajaran Ekonomi Tahun Ajaran 2015/2016. Skripsi. Yogyakarta. Program Studi Pendidikan Ekonomi Fakultas Ekonomi Universitas Negeri Yogyakarta. Dipublikasikan.

Rice, P.F., \& Dolgim, G.K., (2001) The Adolsecent Development Relationship and Culture $10^{\text {th }}$ Edition. Boston: A Pearson Education Company

Rusyan, T.A., dkk (1992). Pendekatan Dalam Proses Belajar Mengajar. Bandung: Remaja Rosdakarya

Santosa, D.T., Tawardjono, U.S., (2016) Faktor - Faktor Penyebab Rendahnya Motivasi Belajar dan Solusi Penanganannya Pada Siswa Kelas XI Jurusan Teknik Sepeda Motor. Jurnal Pendidikan Teknik Otomotif Edisi XIII: 14 (2).

Santrock, J. (2002). Life Span Development (Perkembangan Masa Hidup, Jilid 2, Penerjemah: Chusairi dan Damanik). Jakarta: Erlangga.

(2011). Masa perkembangan anak, edisi kesebelas. Jakarta: Salemba Humanika

Sardiman, A.M.,(2011). Interaksi dan Motivasi Belajar Mengajar. Jakarta : Rajagrafindo.

Uno, H.B. (2011). Teori Motivasi dan Pengukurannya, Analisis di Bidang Pendidikan. Jakarta: PT Bumi Aksara.

Walgito, Bimo (2002). Pengantar Psikologi Umum. Yogyakarta. Andi Offset.

Winkel (1996). Psikologi Pengajaran. Jakarta:Grasindo 
Tabel 1

Uji Normalitas Variabel Penelitian

\begin{tabular}{cccc}
\hline Variabel & $\begin{array}{c}\text { Kolmogorov } \\
\text { Smirnov }\end{array}$ & $\begin{array}{c}\text { Asymp. Sig. (2 } \\
\text { failed) }\end{array}$ & Bentuk \\
\hline Kelekatan & $\mathbf{1 . 2 7 3}$ & .078 & Normal \\
\hline Motivasi Belajar & .608 & .853 & Normal \\
\hline
\end{tabular}

Tabel 2

Uji Linieritas Variabel Penelitian

\begin{tabular}{|c|c|c|c|c|}
\hline & & & $\mathbf{F}$ & Signifikansi \\
\hline Motivasi Belajar * & Between & (Combined) & 1.833 & .007 \\
\hline \multirow[t]{2}{*}{ Kelekatan } & Group & Linearity & 22.781 & .000 \\
\hline & & Deviation From Linearity & 1.357 & .0108 \\
\hline
\end{tabular}

Tabel 3

Uji Korelasi Product Moment Kelekatan Orangtua-Anak dengan Motivasi Belajar

\begin{tabular}{llll}
\hline Pearson Correlation & Motivasi Belajar & Kelekatan & Sig. (2-tailed) \\
\hline Motivasi Belajar & 1 & .356 & .000 \\
\hline Kelekatan & .356 & 1 & .000 \\
\hline
\end{tabular}

Tabel 4

Koefisien Determinasi Penelitian

\begin{tabular}{cc}
\hline $\mathrm{R}$ & Rsquare \\
\hline $\mathbf{0 , 3 5 6}$ & 0,127 \\
\hline
\end{tabular}


Tabel 5

Kategorisasi Kelekatan Orangtua-Anak

\begin{tabular}{cccc}
\hline Rentang Nilai & Kategori & Jumlah & Persentase \\
\hline $\mathbf{X} \leq \mathbf{5 3 , 6 7}$ & Rendah & 2 orang & $1.39 \%$ \\
& & & \\
\hline $\mathbf{5 3 , 6 7} \leq \mathbf{X} \leq \mathbf{8 4 , 3 3}$ & Sedang & 65 orang & $45,46 \%$ \\
& & & $53,15 \%$ \\
\hline $\mathbf{8 4 , 3 3} \leq \mathbf{X}$ & Tinggi & 76 orang & \\
\hline
\end{tabular}

Tabel 6

Kategorisasi Motivasi Belajar

\begin{tabular}{llll}
\hline Rentang Nilai & Kategori & Jumlah & Persentase \\
\hline $\mathbf{X} \leq \mathbf{6 7 , 6 7}$ & Rendah & 3 orang & $2,09 \%$ \\
\hline $\mathbf{6 7 , 6 7} \leq \mathbf{X} \leq \mathbf{1 0 6 , 3 3}$ & Sedang & 113 orang & $79,03 \%$ \\
& & & \\
\hline $\mathbf{1 0 6 , 3 3} \leq \mathbf{X}$ & Tinggi & 27 orang & $18,89 \%$ \\
\hline
\end{tabular}

